\title{
THE HISTORICAL ORIGINS OF THE SOVIET DOCTRINE OF PEACEFUL COEXISTENCE
}

\author{
WARREN LERNER*
}

The history of the doctrine of "peaceful coexistence" in Soviet foreign policy is inseparable from the history of the doctrine of "world revolution." Throughout its history, the Soviet regime has acknowledged fealty to both doctrines but varied the public support for one or the other doctrine according to the objective conditions of the time. Both doctrines lend themselves to sweeping and varied definitions and defy standard descripton. However, for the purposes of this discussion, I have taken the liberty of assigning the following broad definitions to each doctrine: "Peaceful coexistence," within the Soviet experience, is the policy which acknowledges the existence of societies antagonistic to the Soviet regime without regarding the destruction of these societies as the immediate goal of the Soviet state. By the same token, "world revolution" may be defined as a policy based on the premise that since Communist society cannot be secure in a "capitalist encirclement," the primary goal of the Soviet state becomes the destruction of the "capitalist encirclement" and the governments which compose it.

There has generally been a historical interaction between these two doctrines in Soviet foreign policy, with the result usually that the practice of one of these doctrines has been downgraded in order to facilitate the practice of the other at any given time. Since 1956, "peaceful coexistence" has enjoyed a rather intensified promotion in Soviet pronouncements on foreign affairs and has officially been proclaimed as the cornerstone of Soviet foreign policy. At the same time, the very term "world revolution" has been eschewed, and except for avowals of faith in the determinist view of the march of history such as Khrushchev's celebrated remark, "Your grandchildren will live under socialism," the concept has not been directly promoted. In line with this new emphasis on "peaceful coexistence," in I959, Nikita S. Khrushchev offered American readers a reasonably detailed exposition of the Soviet viewpoint in the prominent American journal, Foreign Affairs. In his article, Mr. Khrushchev maintained that the Soviet Union's professsed policy of "peaceful coexistence" was nothing new, that it had always been the policy of the Soviet régime, and that with more than forty years of experience in practicing this policy, Soviet professions of peaceful coexistence should be better received in the West. Going on to prove his case for the historical permanence of "peaceful coexistence" in Soviet doctrine, Khrushchev stated:

From its very inception [in $\mathrm{Igr}_{7}$ ] the Soviet state proclaimed peaceful coexistence as the basic principle of its foreign policy. It was no accident that the very first state act of the

* B.S. 1952, Boston University; M.A. 1954, Certificate of the Russian Institute 1954, Ph.D. 196r, Columbia University. Assistant Professor of History, Duke University, since 196r. 
Soviet power was the decree on peace, the decree on the cessation of the bloody [world] war. ${ }^{1}$

The validity of Mr. Khrushchev's historical claim must, to a certain extent, be reaffirmed. As he points out, immediately after seizing power in Russia, in November I9I7, the Bolsheviks issued a Decree on Peace which inter alia called for all of the participants in World War I to open immediate negotiations for the conclusion of peace. Indeed, Mr. Khrushchev could have added that Leon Trotsky, then the People's Commissar of Foreign Affairs, followed this decree by proclaiming an official doctrine of peaceful coexistence with all peoples. ${ }^{2}$ However, to argue the case of Soviet fidelity to "peaceful coexistence" on the basis of such theoretical pronouncements is to pervert the historical record. What Mr. Khrushchev failed to mention in his article is the fact that in the early years of the Soviet state the doctrine of "world revolution" was also loudly proclaimed; in fact, it was "world revolution" and not "peaceful coexistence" which took precedence in the early formation of Soviet foreign policy. In the years I9I7 to I920, specifically, the belief in the imminence of "world revolution," and the obligation of the Soviet regime to aid and abet this revolution, reduced peaceful coexistence to an occasional slogan, a condition from which it emerged only when the immediate survival of the Soviet regime was at stake or other pragmatic considerations made its espousal desirable.

In I9I8, Lenin and Trotsky were both convinced that the survival of the Soviet regime was absolutely contingent upon the outbreak of proletarian revolution in West Europe and not on "peaceful coexistence." Even in his Decree on Peace, Lenin implied that the workers of the West were expected to join the Russian workers in establishing proletarian regimes. Further statements throughout $x 918$ and I919 spoke alternately of hopes and disappointments in the quest for world revolution. No thought at all was given, at least openly, to the apparent contradiction in this policy: can you preach and practice coexistence with countries and at the same time actively support-and with support by no means limited to sympathythe overthrow of the governments of these countries? There is, of course, a marked difference in applauding a revolution and fostering or directing it.

Soviet relations with Imperial Germany in rgr8 were an apt demonstration of this contradiction in Soviet foreign policy. Lenin, in a "peace at any price" policy, had been forced in March I918, to accept the Draconian terms of the Treaty of Brest-Litovsk. Technically speaking, this treaty created a state of "peaceful coexistence" between Germany and Soviet Russia. Actually the treaty had not been accepted by Lenin out of ideological beliefs but out of sheer necessity. Nevertheless, it represented the first manifestation of "peaceful coexistence"-albeit on terms very unfavorable to the Soviet regime-in practice by the new Bolshevik government. However, on October $\mathrm{I}$, $\mathrm{xg} 8 \mathrm{8}$, sensing a possible chance for a proletarian revolution in a Germany whose armies were on the verge of collapse, Lenin wrote

${ }^{1}$ Khrushchev, On Peaceful Coexistence, 38 Foreign Afrarrs 3 (1959).

23 Leon Trotsky, Sochinenia [Works] pt. 2, at 165 (Moscow, 1926). 
to Trotsky that the Soviet regime ought to supply revolutionary-minded German workers with "brotherly union, bread, and military assistance." Soviet Russia was technically at peace with Germany and allegedly practicing "peaceful coexistence" with it apparently did not inhibit Lenin from proposing military assistance to those who might want to overthrow the German government. The simple answer was to be found in the conflicting interests of world revolution and peaceful coexistence; in this period, the priority of the former over the latter was unquestioned.

During the next several months, the Soviet régime was not able to participate directly in the progress of the German revolution, but this lack of participation was dictated by geography and the lack of a contiguous border-thanks to the resurrection of Poland in 1918-rather than by any qualms about violating peaceful coexistence.

The high point of the crusade for world revolution, regardless of the consequences, came in March 1919, when the Communist International was founded at Lenin's insistence. Though many of the organization's calls to world revolution can be dismissed as revolutionary rhetoric, the founding of a group whose raison d'être was the overthrow of the established governments of the world tarnished the image of a Soviet regime seeking "peaceful coexistence."

The following year, I920, put Soviet intentions vis-à-vis "peaceful coexistence" to their sternest test. Hitherto, Soviet estimates that the West might accept "peaceful coexistence" had been substantially clouded by Western intervention in Russia's civil war on the anti-Bolshevik side. By 1920 , most of this intervention was over and perhaps the Soviet régime was in a better position to consider the realities of "peaceful coexistence" now that the direct military threat was limited to one anti-Bolshevik army in the Ukraine. Furthermore, the failure of Soviet ventures in the West had cooled revolutionary ardor and had made the climate for "peaceful coexistence" a little more relaxed. However, before any serious consideration of a vigorous policy of "peaceful coexistence" could take place, Polish legions invaded the Ukraine and the Russo-Polish War of 1920 was launched.

The Russo-Polish War of 1920 was actually the result of a long-smoldering situation which the Russians had not been anxious to press so long as they were involved in their own civil war. The Polish invasion, however, gave the Soviet régime some second thoughts on relations with non-Communist neighbors. Hitherto, the official policy toward Poland had been one of peaceful coexistence, even if relations had been difficult. After the outbreak of open hostilities in April r920, the Soviet leadership re-evaluated its official position and came to the conclusion that under the circumstances "world revolution" was a better policy to apply in this situation. Hence the Soviet goal in this war became not merely to defeat Poland but to install a Soviet government in Poland. Thus, after the Poles had been driven back, Red Army units crossed into Poland and immediately installed a

\footnotetext{
${ }^{3}$ Reprinted in 21 Lennssir Sbornik [Lenin's Miscellany] 252-53 (I933). (Emphasis added.)
} 
Revolutionary Committee in the Polish city of Bialystok, openly recognizing this committee as the future Soviet government of Poland. The various pronouncements by leading Bolsheviks, especially by Marshal Tukhachevsky, ${ }^{4}$ avowed that the goal of the Red Army was to create a Soviet Poland and beyond that spread the world revolution as far as possible. For a while it appeared that Soviet efforts might be successful, since by August I920, the Red Army was in sight of Warsaw. Only a sensational and daring defense of the city by the Polish general, Josef Pilsudski, frustrated the attempt to convert Poland into the second Soviet state in the world. Failing to take Warsaw, the Red Army offensive lost its momentum and the Poles now drove the Russians back to White Russia. Both sides agreed to an armistice in September, followed by the Treaty of Riga of I92r. The first attempt to spread the world revolution by military force had failed.

The failure of the Russian drive on Warsaw was perhaps the greatest impetus toward the adoption of a policy of "peaceful coexistence" by the Soviet regime. What impressed Lenin was not the military aspect of the defeat but the fact that the proletariat of Poland fought not on the side of the Bolsheviks but on the side of its own "bourgeois" Polish government. It was this failure of the Red Army to impose a Soviet regime on Poland in rgzo and not, as Khrushchev maintains, the Decree on Peace of $x 917$, that gave birth to the serious pursuit of "peaceful coexistence."

That Lenin himself had finally recognized that "world revolution" was not imminent is implicit in his assessment of the Russo-Polish War, contained in a speech on foreign policy which he delivered in Moscow on October 2, 1920:

If Poland had become Soviet . . . the entire international system built by the victors [of World War I] would have been destroyed. ... However, it turned out that although events are moving inexorably toward the workers' revolution, they are still moving too slowly as compared to the rapidity of events in Russia. ${ }^{5}$

While Lenin had previously conceded difficulties with various revolutionary situations, hitherto he had consistently expressed confidence in the immediate potential for world revolution. With the failure of the Polish campaign, the period of the militant quest for world revolution had come to an end; and it now became expedient to put into practice the doctrine of "peaceful coexistence."

The chief practitioner of the newly revived doctrine of "peaceful coexistence" was the polished and skillful Georgi Chicherin, since mid-rgr8 People's Commissar of Foreign Affairs. So successful was Chicherin in marketing the image of "peaceful coexistence" that by 1925 every major country in the world, with the notable exception of the United States, had extended diplomatic recognition to the Soviet régime. With some countries, notably Weimar Germany, Chicherin not only established peaceful relations but extensive trade contacts as well. Yet at the same time, the Communist International, an organization of Communist Parties of the world, continued to pursue an active policy of world revolution, promoting revolutionary

\footnotetext{
'See, for example, M. N. Tukhachevsky, Vorsa KIsssov [Class War] 138-40 (1929).

- Reprinted in $4 \mathrm{I}$ V.I. Lenin, Poldoe Sobranie Sochinenir [Complete Collected Works] 324-25 (5th ed. 1963 ).
} 
putsches in Germany, Bulgaria, and China-albeit with rather ludicrous results. Although the Communist International was supposedly devoid of any control by the Soviet régime, it was based in Moscow, led and controlled by Bolsheviks, and its major strategy determined by Lenin and his Politburo. If the Communist International, with rather open Bolshevik control, actively sought the overthrow of foreign governments, could the Soviet Union be said to be pursuing a policy of peaceful coexistence? The question became somewhat academic in the latter half of the Ig20s when, after Lenin's death and the ascendancy of Stalin over Trotsky, the Communist International became a far less active organization whose meetings became rarer and rarer and whose members' major preoccupation became purging dissidents rather than capitalists.

If the first major step in making "peaceful coexistence" a Soviet policy came with the end of the Russo-Polish War, the second major step came with Stalin's introduction of the doctrine of "socialism in one country." This doctrine, first introduced by Stalin in 1924, and adopted by the Soviet Communist Party in the wake of Stalin's triumph, substantially downgraded the importance of world revolution. "Socialism in one country" involved such a total commitment of Soviet resources in the home country that "peaceful coexistence" not only became feasible but highly necessary. During the period of the first two Five Year Plans, that is, I928-r938, the Soviet Union did all it could do to enhance the impression that it had no ambitions beyond its borders and was distressed lest anyone else have such ambitions. With the emergence of a Nazi régime in Germany in 1933, the Soviet Union, with its Foreign Office now under the direction of Maxim Litvinov, sought international respectability in the West as ardently as they had sought world revolution in the early years of the régime. The Soviet Union joined the League of Nations (a deliberate manifestation of support for "peaceful coexistence"), signed defense pacts with Western nations, and unlike the Ig20s refrained from foreign adventuresalthough it could not resist meddling in the Spanish Civil War. This policy was all well and good for the cause of "peaceful coexistence," but what of "world revolulution?" Had Stalin in more or less pursuing peaceful coexistence more or less abandoned world revolution? From his exile in the West, Trotsky indicted Stalin for moving the goals of Soviet foreign policy "from world revolution to the status quo."

An explanation of the new Soviet policy was offered to the outside world by one of Stalin's chief publicists, Karl Radek. In an article in Foreign Affairs, offered as official interpretation of Soviet doctrine, Radek emphasized the willingness of the Soviet Union to seek peaceful relations with all powers and downplayed as much as he could the theme of world revolution. As for the latter doctrine, Radek offered the rather apocalyptic view that once workers in other lands had seen the triumph of "socialism in one country," they would seek to emulate the Soviet example. Considering Radek's earlier background as a rather militant-and sometimes irresponsible-advocate of revolutionary action, the dim and far-off-and maybe

- Radek, The Bases of Soviet Foreign Policy, I2 Foreign AfFarrs 193 (r934). 
never-view of world revolution went far to establish the official priority of "peaceful coexistence" over "world revolution."

Actually, for some purposes, Stalin had done too good a job of selling "peaceful coexistence" and in some respects had seemed to confirm Trotsky's charge that Stalin had betrayed "world revolution." In 1938 , through the medium of his public letter to one Comrade Ivanov, Stalin reaffirmed his faith in eventual "world revolution":

Hence the support of our revolution by the workers of all countries, and still more, the victory of the workers in at least several countries, is a necessary condition for fully guaranteeing the first victorious country [U.S.S.R.] against any attempts at intervention and restoration, a necessary condition for the final victory of socialism.?

The outbreak of World War II in I939 forced a complete re-evaluation of Soviet foreign policy. Stalin, after protecting himself with a non-aggression pact with Hitler, still had the opportunity to follow a path of "peaceful coexistence" had he so desired. Quite to the contrary, however, 1939 effectively marked a major interruption in the Soviet practice of "peaceful coexistence." The Soviet record from 1939 to $194 \mathrm{I}-\mathrm{a}$ period when the Soviet Union was officially neutral in World War II-was marked by military aggression against Poland, Romania, the Baltic States, and Finland; and resulted in the militant spread of Bolshevism to all of the Baltic States and portions of other states. This policy was interrupted by the German invasion of the Soviet Union in I94r and the dire military plight of Russia for the next few years. Once the German military threat was repulsed, however, Soviet foreign policy renewed its militancy of the I939-I94I period and again converted the Red Army into an instrument of world revolution. As the Red Army marched westward, it brought in its wake Soviet governments, exported from Moscow to take over the countries of East Europe. "Peaceful coexistence" was on the Soviet agenda only after the Moscow-exported governments were installed in power. From the end of World War II until Stalin's death in 1953, it was difficult to take Soviet professions of "peaceful coexistence" seriously; the record in East Europe seemed to indicate a policy much more concerned with "world revolution."

With Stalin's death, Soviet relations with the West became more stable than they had been since I939. Once again, the prospects for further military expansion dimmed. The I950s appeared to be a more suitable time for consolidating gains than for new conquests. As in the past, the doctrine of "peaceful coexistence" was now trotted out and loudly proclaimed. Khrushchev may have claimed that he was only continuing the eternal policy of the Soviet state, but more serious reflection will indicate that be it under Khrushchev, Stalin, or Lenin, "peaceful coexistence" has been adopted by the Soviet Union as a pragmatic measure and not as an inherent belief. "World revolution," on the other hand, is inherent in Communist doctrine; and should the international situation offer new opportunities, it might again supplant "peaceful coexistence" as it has in the past.

'First published in 4 Bol'shevik, p. 14 (Feb. 15, 1938). 